\title{
Natural hemoplasma infection of cats in Cuiaba, Mato Grosso, Brazil
}

\section{Hemoplasmas em felinos domésticos naturalmente infectados em Cuiabá, Mato Grosso, Brasil}

\author{
Herica Makino할 Daphine Ariadne Jesus de Paula ${ }^{1}$; Valéria Régia Franco Sousa ${ }^{2}$; \\ Adriane Jorge Mendonça ${ }^{2}$; Valéria Dutra²; Luciano Nakazato²; Arleana do Bom \\ Parto Ferreira de Almeida ${ }^{2 *}$
}

\begin{abstract}
The aim of this research was to investigate natural hemoplasma infection in cats treated at the Veterinary Hospital of the Federal University of Mato Grosso, and the factors associated with infection. Blood samples from 151 cats of different sexes, breeds, and ages were analyzed by PCR and blood count. The overall occurrence of hemoplasma was $25.8 \%$. Mycoplasma haemofelis (Mhf), 'Candidatus Mycoplasma haemominutum (CMhm)', and 'Candidatus Mycoplasma turicensis' (CMt) were observed in $15.2 \%, 14.6 \%$ and $2.6 \%$ of cats, respectively. In $6.6 \%$ of cases, co-infection was observed. Male felines or mixed breed cats were associated with infection by $\mathrm{CMhm}(\mathrm{P}=0.02$ and 0.04 , respectively). The data obtained demonstrated an occurrence of $25.8 \%$ for hemoplasma infection in felines coming from clinical care in the city of Cuiabá, where males were at higher risk of acquiring the infection by these agents, in addition to a higher risk for $\mathrm{CMhm}$ in felines with no specific breed.
\end{abstract}

Key words: Feline. Mycoplasma. PCR. Occurrence. Hemoplasma.

\section{Resumo}

O objetivo desta pesquisa foi investigar a ocorrência de Mycoplasma haemofelis (Mhf), 'Candidatus Mycoplasma haemominutum' (CMhm) e 'Candidatus Mycoplasma turicensis' (CMt) em felinos atendidos no Hospital Veterinário da Universidade Federal de Mato Grosso e os fatores associados à positividade. Amostras de sangue de 151 felinos, dos distintos gêneros, raças e idades foram analisadas pela PCR e hemograma. A ocorrência geral de hemoplasmas foi de $25,8 \%$ e positividade para Mhf, CMhm e CMt foi observada em $15,2 \%, 14,6 \%$ e $2,6 \%$ felinos, respectivamente. Em $6.6 \%$ dos casos foi observado co-positividade. Apenas a variável sexo, macho $(\mathrm{p}=0,02)$, foi associada à positividade para hemoplasmas. Felinos sem raça definida foram associados à positividade para $\mathrm{CMhm}(\mathrm{p}=0,04)$. Os dados obtidos demonstram prevalência de $25,8 \%$ para hemoplasmas em felinos provenientes de atendimento clínico do Hospital Veterinário da UFMT, onde os machos apresentaram maior risco de adquirir a infecção por estes agentes, além de maior risco para CMhm nos felinos sem definição racial. Palavras-chave: Felinos. Mycoplasma. PCR. Ocorrência. Hemoplasma.

\footnotetext{
' Discentes, Curso de Doutorado, Programa de Pós-Graduação em Ciências Veterinárias, Universidade Federal de Mato Grosso, UFMT, Cuiabá, MT, Brasil. E-mail: hericamak@hotmail.com; daphine.depaula@gmail.com

2 Profs., Faculdade de Medicina Veterinária, FAVET, UFMT, Cuiabá, MT, Brasil. E-mail: valeriaregia27@gmail.com; adrianejorge.m@gmail.com; valeriadutra.dutra@gmail,com; lucnak@ufmt.br; arleferreira@gmail.com

* Author for correspondence
} 
Hemotropic mycoplasmas, or hemoplasmas, comprise a group of bacteria that can induce hemolytic anemia. They have a wide geographic distribution and diversity of hosts, and are the etiological agents in some zoonotic diseases (BIONDO et al., 2009; STEER et al., 2011).

In cats, Mycoplasma haemofelis (Mhf) is the most pathogenic species, while 'Candidatus Mycoplasma haemominutum' (CMhm) and 'Candidatus Mycoplasma turicensis' (CMt) are less pathogenic (SYKES, 2010). The Candidatus designation reflects a provisional classification in the nomenclature, since its characterization is not possible by in vitro culture. Although Mycoplasma haemofelis is also not cultivable, its nomenclature is based on a preexisting species (Haemobartonella felis); thus, the denomination Candidatus not attributed to it (TASKER, 2010).

Infection with these species is considered opportunistic, and under immunosuppressive conditions can induce intense hemolytic anemia and death (BARKER; TASKER, 2013). However, in infected cats that do not have a predisposing factor, Mycoplasma, particularly Mycoplasma haemofelis, can be considered the primary pathogen (GRACE; NORSWORTHY, 2011).

Although the transmission mechanism is not yet fully understood, vector infection by the Ctenocephalides felis family flea, blood transfusion, and bites from infected felines have been identified as possible means of infection (WILLI et al., 2007). Infected felines, depending on the agent involved, may be asymptomatic or present with pale mucous membranes, lethargy, anorexia, weight loss, depression, and fever (BRAGA et al., 2012). Hematologic changes, such as normochromic macrocytic anemia, can be observed, however the diagnosis is based on cytological examination obtained from blood smears and polymerase chain reaction (JENKINS et al., 2013).

Regarding the worldwide distribution, the prevalence of hemoplasma infection in felines varies according to the region and population studied (AQUINO et al., 2014). In Brazil, studies show a prevalence of $6.5 \%$ (BORTOLI et al., 2012) to 36.4 $\%$ (SANTIS et al., 2014). Thus, it is important to study this disease and its associated factors, making possible an epidemiological study of the agents in the city of Cuiabá, state of Mato Grosso.

The felines studied in this research where under clinical care of a university veterinary hospital from September 2010 to September 2012, chosen randomly without distinction of age, sex, or breed. For the sample calculation, a prevalence of $12 \%$ was calculated (MACIEIRA et al., 2007), at $95 \%$ confidence interval and an acceptable error of $5 \%$, totaling 151 animals, considering the total feline population treated over the study duration was 2000 cats. The inclusion criterion for the animals was the consent of the owner, to allow the collection of biological samples necessary for the development of the study. Blood samples were collected in $10 \%$ Sodium Anticoagulant (EDTA) tubes by puncturing the cephalic or jugular vein. Biological samples for molecular testing were stored in microtubes at -20 ${ }^{\circ} \mathrm{C}$ until the time of use. The information, breed, age, sex, and reason for the consultation were obtained from the medical record. Hematological analysis was performed on the pocH-100 iv Diff Automatic Hematology Analyzer (Roche), with anemia considered as a hematocrit value of $<24 \%$ (JAIN, 1993).

DNA extraction from the blood samples was performed using the phenol/chloroform method (SAMBROOK; RUSSELL, 2001). To verify the presence of PCR inhibitors in the DNA samples, the samples were tested for the GAPDH gene, with the oligonucleotides: GAPDHF ( 5 ' - C C T TCAT T GA CC TCAACTACAT-3') and GAPDHF ( 5 ' -CCAAA GTTGTCATGGATGACC-3'), according to Birkenheuer et al. (2003). DNA quantification was determined by absorbance with a NanoDrop ND-1000 ${ }^{\circledR}$ spectrophotometer at wavelengths of 260 and $280 \mathrm{~nm}$ (UV light), obtaining 
an average of $77.7 \pm 81.7$. For the detection of $\mathrm{Mhf}$ and $\mathrm{CMhm}$, synthetic oligonucleotides, based on the 16S RNA region were used: OH-OK (Mhf-specific 5'-ATGCCCCTCTGTGGGGGATAGCCG-3'), CA-B2 (CMhm-specific 5'-CTGGGAAACTAGAGCTTCGCGAGC-3'), and 00CR-r1 (common to the two species, 5'-ATGGTATTGCTCCATCAGACTTTCG-3') which amplify a region of 273 and 202 bp respectively (WATANABE et al., 2003). PCR was performed in a final volume of $25 \mu \mathrm{l}$, with each reaction containing $10 \mathrm{ng} \mathrm{DNA}, 50 \mathrm{mM} \mathrm{MgCl}_{2}, 10$ $X$ Taq Buffer with $50 \mathrm{mM} \mathrm{KCl}, 1 \mathrm{mM}$ dNTP, 20 pmol of each oligonucleotide, and $1 \mathrm{U}$ of Taq DNA polymerase $\left(\right.$ Fermentas $\left.^{\circledR}\right)$. PCR conditions were: initial denaturation for 4 minutes at $94{ }^{\circ} \mathrm{C}, 30$ cycles of denaturation for 45 seconds at $94{ }^{\circ} \mathrm{C}$, annealing for 45 seconds at $56.8{ }^{\circ} \mathrm{C}$ and extension for 45 seconds at $72{ }^{\circ} \mathrm{C}$, followed by a final extension cycle of 5 minutes at $72{ }^{\circ} \mathrm{C}$ in a thermocycler (MyCyclerBiorad).

CMt detection was performed according to Peters et al. (2008), using the CMt-F oligonucleotides (5'-AGAGGCGAAGGCGAAAACT-1-3') and CMt-R (5'-CTACAACGCCGAAACACAAA-3'), which amplify a region of $202 \mathrm{bp}$. PCR was composed of a final volume of $25 \mu \mathrm{l}$, using $10 \mathrm{ng}$ of DNA, $1.5 \mathrm{U}$ of Taq DNA polymerase (Fermentas ${ }^{\circledR}$ ), $50 \mathrm{mM} \mathrm{MgCl}, 10$ x Taq Buffer with $50 \mathrm{mM} \mathrm{KCl}$, $1 \mathrm{mM}$ dNTP, and $20 \mathrm{pmol}$ of each oligonucleotide. The reaction was also performed in thermal cycler $\left(\right.$ MyCycler-Biorad $\left.^{\circledR}\right)$, with initial denaturation for 4 minutes at $94{ }^{\circ} \mathrm{C}, 35$ cycles of 10 seconds for denaturation at $95{ }^{\circ} \mathrm{C}, 30$ seconds annealing at 58 ${ }^{\circ} \mathrm{C}$ and 30 seconds extension at $72{ }^{\circ} \mathrm{C}$, followed by a final extension cycle for 5 minutes at $72{ }^{\circ} \mathrm{C}$. Amplification products were analyzed by gelRed $\left(\right.$ Biotium $^{\circledR}$ ) stained gel electrophoresis and observed on ChemiDoc ${ }^{\mathrm{TM}}$ XRS using Image Lab ${ }^{\mathrm{TM}}$ Software and a 100 bp molecular mass marker of LadderTM DNA (Fermentas ${ }^{\circledR}$.

The data were statistically analyzed by chisquare or Fisher's exact tests, using EpiInfo 3.3.2
(CDC, Atlanta, USA), to verify the association between the independent variables and infection by Mhf, CMhm, and CMt, with $\mathrm{p} \leq 0.05$ considered as significant.

Of the 151 felines evaluated, $39(25.8 \%$ [CI 19.2-32.8]) were positive in the PCR assays for hemoplasma. Positivity for Mhf, CMhm, and CMt was observed in 23 (15.2\% [CI 9.3-21.2]), 22 (14.6 $\%$ [CI 9.3-20.5]) and 4 (2.6\% [CI 0.7-5.3]) cats, respectively. Co-positivity was observed in 10 (6.6 $\%$ [CI 3.3-10.6]) cats, nine (90\%) of which were copositive for Mhf and Mhm, and only one (10\%) for Mhf and CMt. Cases of co-positivity were detected only in male cats.

Male cats had twice the chance $(p=0.02)$ of being positive for hemoplasma (OR 2.68 [1.216.27]) (Table 1). In the analysis of the factors associated to each species, the sex variable also presented a significant difference in positivity for $\operatorname{Mhf}(\mathrm{p}=0.01)$ and $\operatorname{Mhm}(\mathrm{p}=0.02)$, with a risk four (OR 4.15 [1.41-14.96]) and three (OR 3.88 [1.3014.03]) times greater for the male felines being positive, respectively. Regarding the influence of breed, non-defined felines did not present a statistically significant difference for hemoplasma infection $(\mathrm{p}=0.2)$, but in the analysis for each hemoplasma, the non-defined felines had a higher chance (OR 3.04 [1.02-8.56]) of positivity for CMhm $(p=0.04)$. Anemia was observed in $23(15.2$ $\%$ ) of the felines surveyed, of which only five (12.8 $\%$ ) were positive for hemoplasma, and of these, two presented positivity for Mhf, one for Mhm, and two co-positivity for Mhf and Mhm.

The prevalence of hemoplasmas in felines has already been described in several regions of Brazil. In this study, the prevalence of $25.8 \%$ for hemoplasmas was lower than that obtained by SANTIS et al. (2014) and André et al. (2014) in Mato Grosso do Sul and São Paulo, respectively, but higher than those obtained in other Brazilian regions (BRAGA et al., 2012; AQUINO et al., 2014) and other countries (GHAZISAEEDI et al., 
2014; DUARTE et al., 2015). According to Aquino et al. (2014), the difference in prevalence may arise from the study population. In this research, a high prevalence of felines originated from veterinary hospitals, in contrast to the prevalence of $8.4 \%$ in cats predominantly from animal pound observed by Miceli et al. (2013) in the same municipality.

Table 1. Prevalence of Mycoplasma haemofelis, 'Candidatus Mycoplasma haemominutum' and 'Candidatus Mycoplasma turicensis' infection in Cuiabá felines, Mato Grosso and factors associated with hemoplasma infection.

\begin{tabular}{|c|c|c|c|c|c|c|}
\hline \multirow{2}{*}{ Variables } & \multicolumn{3}{|c|}{ Positive felines } & \multirow{2}{*}{ Total (+/\%) } & \multirow{2}{*}{$\mathrm{P}$} & \multirow{2}{*}{ OR (IC 95\%) } \\
\hline & Mhf* & CMhm* & $\mathrm{CMt}^{*}$ & & & \\
\hline \multicolumn{7}{|l|}{ Gender } \\
\hline Male & 19 & 18 & 02 & $87(39 / 44.8)$ & \multirow{2}{*}{0.02} & 2.68 \\
\hline Female & 04 & 04 & 02 & $64(10 / 15.6)$ & & $(1.21-6.27)$ \\
\hline \multicolumn{7}{|l|}{ Breed } \\
\hline SRD** & 17 & 15 & 04 & $127(36 / 28.4)$ & \multirow{2}{*}{0.2} & \\
\hline CRD** & 06 & 07 & 00 & $24(13 / 54.2)$ & & \\
\hline \multicolumn{7}{|l|}{ Age groups } \\
\hline$<1$ year & 07 & 06 & 02 & $59(14 / 23.7)$ & \multirow{5}{*}{0.3} & \multirow{5}{*}{----- } \\
\hline $1-4$ years & 07 & 07 & 01 & $40(15 / 37.5)$ & & \\
\hline $4-8$ years & 05 & 07 & 01 & $24(13 / 54.2)$ & & \\
\hline$>8$ years & 02 & 02 & 00 & $13(04 / 23.1)$ & & \\
\hline Indefinite age & 02 & 00 & 00 & $15(02 / 13.3)$ & & \\
\hline
\end{tabular}

*Mhf - Mycoplasma haemofelis; CMhm - 'Candidatus Mycoplasma haemominutum'; 'Candidatus Mycoplasma turicensis' **SRD - Without defined Race; **CRD - With defined Race.

The occurrence of the infection by the different species may also reflect the population studied. The highest occurrence of Mhf infection was similar to that obtained by Ghazisaeedi et al. (2014) who investigated cats coming from clinical care, a fact that may be justified by the greater pathogenicity of this agent. However, CMhm has also been the most prevalent species in feline hemoplasma studies, independent of the population studied (JENKINS et al., 2013; SANTIS et al., 2014; SPADA et al., 2014), and this agent was the second-most prevalent in this study, but it was the most frequently found by Miceli et al. (2013).

Co-positivity for the different species of hemoplasma has been described in felines, mainly among the most prevalent species in the region, and tends to prevail in male felines (SANTOS et al., 2014; DUARTE et al., 2015), as also found in this study. Male felines may be at increased risk for hemoplasma infection due to frequent fights over territory disputes and females in estrus (JENKINS et al., 2013; RAIMUNDO et al., 2016). Although the association of Mhm infection with anemia has already been described in other studies (SANTOS et al., 2014), in this study no association with anemia was observed by any of the investigated agents, although the feline population came from a veterinary hospital similar to the studies of Aquino et al. (2014), Spada et al. (2014), and Vergara et al. (2016).

The results of this study demonstrated the efficacy of the molecular method for the detection 
of hemoglobin in the laboratory. Oligonucleotides designed by Watanabe et al. (2003) and Peters et al. (2008) had a high percentage of homology (up to $98 \%$ ) with the genomes of the ribosomal gene of the different species. Despite the gene similarity between these organisms, about 83\% (HARVEY, 2006) between Mhf and CMhm, the non-specificity between reactions would be very low. Although the PCR technique is sensitive and specific, it still does not replace the power of sequencing detection. However, for this technique, longer amplification products covering a larger region of the 16SRNA gene $(1 \mathrm{~kb})$ would be required, which was not possible with the oligonucleotides used in the experiment. Several oligonucleotides have been used for the detection of hemoplasma in felines, however there are no in-depth studies comparing their specificity levels and sensitivity.

The data obtained demonstrated a prevalence of $25.8 \%$ for hemoplasma infection in felines coming from clinical care in the city of Cuiabá, where males presented a higher risk of infection by these agents, as well as a higher risk for $\mathrm{CMhm}$ in felines no specific breed.

\section{Committee on ethics and biosafety}

This study was approved by the Committee on Ethics in the Use of Animals (CEUA-UFMT) \# 23108.015198 / 11-4.

\section{References}

ANDRÉ, M. R.; DENARDI, N. C. B.; SOUSA, K. C. M. de; GONÇALVES, L. R.; HENRIQUE, P. C.; ONTIVERO, C. R. G. R.; GONZALEZ, I. H. L.; NERY, C. V. C.; CHAGAS, C. R. F.; MONTICELLI, C.; SANTIS, A. C. G. A.; MACHADO, R. Z. Arthropodborne pathogens circulating in free-roaming domestic cats in a zoo environment in Brazil. Ticks and Tick-borne Diseases, Amsterdam, v. 5, n. 5, p. 545-551, 2014.

AQUINO, L. C.; HICKS, C. A.; SCALON, M. C.; LIMA, M. G. D. M.; LEMOS, M. D. S.; PALUDO, G. R.; HELPS, C. R.; TASKER, S. Prevalence and phylogenetic analysis of haemoplasmas from cats infected with multiple species. Journal of Microbiological Methods, Amsterdam, v. 107, p. 189-196, 2014.

BARKER, E.; TASKER, S. Haemoplasmas: lessons learnt from cats. The New Zealand Veterinary Journal, Wellington, v. 61, n. 4, p. 184-192, 2013.

BIONDO, A. W.; SANTOS, A. P. dos; GUIMARÃES, A. M. S.; VIEIRA, R. F. D. C.; VIDOTTO, O.; MACIEIRA, D. D. B.; ALMOSNY, N. R. P.; MOLENTO, M. B.; TIMENETSKY, J.; MORAIS, H. A. de; GONZÁLEZ, F. H. D.; MESSICK, J. B. A review of the occurrence of Hemoplasmas (Hemotrophic Mycoplasmas) in Brazil. Brazilian Journal of Veterinary Parasitology, v. 18, n. 3, p. 1-7, 2009.

BIRKENHEUER, A. J.; LEVY, M. G.; BREITSCHWERDT, E. B. Development and Evaluation of a Seminested PCR for Detection and Differentiation of Babesia gibsoni (Asian Genotype) and B. canis DNA in Canine Blood Samples. Journal of Clinical Microbiology, v. 41, n. 9, p. 4172-4177, 2003.

BRAGA, M. S. C. O.; ANDRÉ, M. R.; FRESCHI, C. R.; TEIXEIRA, M. C. A.; MACHADO, R. Z. Molecular detection of hemoplasma infection among cats from São Luís Island, Maranhão, Brazil. Brazilian Journal of Microbiology, Rio de Janeiro, v. 43, n. 2, p. 569-575, 2012.

BORTOLI, C. P.; ANDRÉ, M. R.; SEKI, M. C.; PINTO, A. A.; MACHADO, S. D. T. Z.; MACHADO, R. Z. Detection of Hemoplasma and Bartonella species and coinfection with retroviruses in cats subjected to a spaying/ neutering program in Jaboticabal, SP, Brazil. Revista Brasileira de Parasitologia Veterinária, Jaboticabal, v. 21, n. 3, p. 219-223, 2012.

DUARTE, A.; MARQUES, V.; CORREIA, J. H. D.; NETO, I.; BRÁZ, B. S.; RODRIGUES, C.; ROSADO, T. F.; FERREIRA, J. P.; SANTOS-REIS, M.; TAVARES, L. Molecular detection of haemotropic Mycoplasma species in urban and rural cats from Portugal. Journal of Feline Medicine and Surgery, London, v. 17, n. 6, p. 516-522, 2015.

GHAZISAEEDI, F.; ATYABI, N.; ZAHRAI SALEHI, T.; GENTILINI, F.; ASHRAFI TAMAI, I.; AKBAREIN, H.; TASKER, S. A molecular study of hemotropic mycoplasmas (hemoplasmas) in cats in Iran. Veterinary Clinical Pathology, Baton Rouge, v. 43, n. 3, p. 381-386, 2014.

GRACE, S. F.; NORSWORTHY, G. D. Hemoplasmosis. In: NORSWORTHY, G. D.; GRACE, S. F.; CYSTAL, M. A.; TILLEY, L. P. The feline patient. $4^{\text {th }}$ ed. Ames: Wiley-Blackwell, 2011. Cap. 92, p. 218-219. 
HARVEY, J. W. Hemotrophic mycoplasmosis (Hemobartonellosis). In: GREENE, C. E. Infectious diseases of the dog and cat. $3^{\text {th }}$ ed. St. Louis: Saunders Elsevier, 2006. cap. 31, p. 252- 260.

JAIN, N. C. Essencials of veterinary hematology. Philadelphia: Lea e Febiger, 1993. 417 p.

JENKINS, K. S.; DITTMER, K. E.; MARSHALL, J. C.; TASKER, S. Prevalence and risk factor analysis of feline haemoplasma infection in New Zealand domestic cats using a real-time PCR assay. Journal of Feline Medicine and Surgery, London, v. 15, n. 12 p. 1063-1069, 2013.

MACIEIRA, D. B.; MENEZES, R. C.; DAMICO, C. B.; ALMOSNY, N. R.; MCLANE, H. L.; DAGGY, J. K.; MESSICK, J. B. Prevalence and risk factors for hemoplasmas in domestic cats naturally infected with feline immunodeficiency virus and/or feline leukemia virus in Rio de Janeiro-Brazil. Journal of Feline Medicine and Surgery, v. 10, n. 2, p. 120-129, 2007.

MICELI, N. G.; GAVIOLI, F. A.; GONÇALVES, L. R.; ANDRÉ, M. R.; SOUSA, V. R. F.; SOUSA, K. C. M. D.; MACHADO, R. Z. Molecular detection of feline arthropod-borne pathogens in cats in Cuiabá, state of Mato Grosso, central-western region of Brazil. Revista Brasileira de Parasitologia Veterinária, Jaboticabal, v. 22, n. 3, p. 385-390, 2013.

PETERS, I. R.; HELPS, C. R.; WILLI, B.; HOFMANNLEHMANN, R.; TASKER, S. The prevalence of three species of feline haemoplasmas in samples submitted to a diagnostic service as determined by three novel real-time duplex PCR assays. Veterinary Microbiology, Amsterdam, v. 126, n. 1-3, p. 142-150, 2008.

RAIMUNDO, J. M.; GUIMARÃES, A.; RODRIGUES, R. B.; BOTELHO, C. F. M.; PEIXOTO, M. P.; PIRES, M. S.; MACHADO, C. H.; SANTOS, H. A.; MASSARDI, C. L.; ANDRÉ, M. R.; MACHADO, R. Z.; BALDANI, C. D. Hematological changes associated with hemoplasma infection in cats in Rio de Janeiro, Brazil. Revista Brasileira de Parasitologia Veterinária, Jaboticabal, v. 25, n. 4, p. 441-449, 2016.

SAMBROOK, J.; RUSSELL, D. W. Molecular cloning: a laboratory manual. New York: Cold Spring Harbor Laboratory Press, 2001. 2100 p.

SANTIS, A. C. G. A. D.; HERRERA, H. M.; SOUSA, K. C. M. D.; GONÇALVES, L. R.; DENARDI, N. C. B.; DOMINGOS, I. H.; CAMPOS, J. B. V.; MACHADO, R. Z.; ANDRÉ, M. R. Molecular detection of hemotrophic mycoplasmas among domiciled and free-roaming cats in Campo Grande, state of Mato Grosso do Sul, Brazil. Revista Brasileira de Parasitologia Veterinária, Jaboticabal, v. 23, n. 2, p. 231-236, 2014.
SANTOS, A. P. D.; CONRADO, F. D. O.; MESSICK, J. B.; BIONDO, A. W.; OLIVEIRA, S. T. D.; GUIMARAES, A. M. S.; NASCIMENTO, N. C.; PEDRALLI, V.; LASTA, C. S.; GONZÁLEZ, F. H. D. Hemoplasma prevalence and hematological abnormalities associated with infection in three different cat populations from Southern Brazil. Revista Brasileira de Parasitologia Veterinária, Jaboticabal, v. 23, n. 4, p. 428-434, 2014.

SPADA, E.; PROVERBIO, D.; GALLUZZO, P.; DELLA PEPA, A.; BAGNAGATTI DE GIORGI, G.; PEREGO, R.; FERRO, E. Prevalence of haemoplasma infections in stray cats in northern Italy. ISRN Microbiology, Cairo, v. 2014, p. 1-9, 2014.

STEER, J. A; TASKER, S; BARKER, E. N; JENSEN, J; MITCHELL, J; STOCKI, T; CHALKER, V. J; HAMON, M. A novel hemotropic Mycoplasma (hemoplasma) in a patient with hemolytic anemia and pyrexia. Clinical Infectious Diseases, v. 53, n. 11, p. 147-151, 2011.

SYKES, J. E. Feline hemotropic micoplasmas. Journal of Veterinary Emergency and Critical Care, Malden, v. 20, n. 1, p. 62-69, 2010.

TASKER, S. Haemotropic mycoplasmas: what's their real significance in cats? Journal of Feline Medicine \& Surgery, v. 12, n. 5, p. 369-381, 2010.

VERGARA， R. W.; GALLEGUILLOS, F. M.; JARAMILLO, M. G.; ALMOSNY, N. R. P.; MARTÍNEZ, P. A.; BEHNE, P. G.; ACOSTA-JAMMET, G.; MÜLLER, A. Prevalence, risk factor analysis, and hematological findings of hemoplasma infection in domestic cats from Valdivia, Southern Chile. Comparative Immunology, Microbiology and Infectious Diseases, Exeter, v. 46, p. 20-26, 2016.

WATANABE, M.; HISASUE, M.; HASHIZAKI, K.; FURUICHI, M.; OGATA, M.; HISAMATSU, S.; OGI, E.; HASEGAWA, M.; TSUCHIYA, R.; YAMADA, T. Molecular detection and characterization of Haemobartonella felis in domestic cats in Japan employing sequence-specific polymerase chain reaction (SS-PCR). Journal of Veterinary Diagnostic Investigation, Thousand Oaks, v. 65, n. 10, p. 1111-1114, 2003.

WILLI, B.; BORETTI, F. S.; TASKER, S.; MELI, M. L.; WENGI, N.; REUSCH, C. E.; LUTZ, H.; HOFMANNLEHMANN, R. From Haemobartonella to hemoplasma: molecular methods provide new insights. Veterinary Microbiology, Amsterdam, v. 125, n. 3, p. 197-209, 2007. 